\title{
14. OXYGEN ISOTOPE AND SAPROPEL STRATIGRAPHY IN THE EASTERN MEDITERRANEAN DURING THE LAST 3.2 MILLION YEARS ${ }^{1}$
}

\author{
D. Kroon, ${ }^{2}$ I. Alexander, ${ }^{2}$ M. Little, ${ }^{2}$ L.J. Lourens, ${ }^{3}$ A. Matthewson, ${ }^{2}$ A.H.F. Robertson, ${ }^{2}$ and T. Sakamoto ${ }^{4}$
}

\begin{abstract}
Stable oxygen isotope data from four holes drilled at the Ocean Drilling Program Site 967, which is located on the lower northern slope of the Eratosthenes Seamount, provide a continuous record of Eastern Mediterranean surface-water conditions during the last 3.2 Ma. A high-resolution stratigraphy for the Pliocene-Pleistocene sequence was established by using a combination of astronomical calibration of sedimentary cycles, nannofossil stratigraphy, and stable oxygen isotope fluctuations. Sapropels and color cycles are present throughout the last 3.2 Ma at Site 967, and their ages, as determined by calibration against the precessional component of the astronomical record, are consistent with those estimated for the sapropels of the classical land-based marine sequences of the Punta Piccola, San Nicola, Singa, and Vrica sections (southern Italy). The Site 967 oxygen isotope record shows large amplitude fluctuations mainly caused by variations in surface water salinity throughout the entire period. Spectral analysis shows that fluctuations in the $\delta^{18} \mathrm{O}$ record were predominantly influenced by orbital obliquity and precessional forcing from 3.2 to $1 \mathrm{Ma}$, and all main orbital frequencies characterize the $\delta^{18} \mathrm{O}$ record for the last million years. The start of sapropel formation at 3.2 Ma indicates a possible link between sapropel formation and the build up of northern hemisphere ice sheets. The dominance of the obliquity cycle in the interval from 3.2-1 Ma further points to the sensitivity of Eastern Mediterranean climate to the fluctuations in the volume of Arctic ice sheets. An intensification of negative isotope anomalies at Site 967, relative to the open ocean, supports a link between high run-off (during warm periods) and sapropel formation. freshwater input would have inhibited deep-water formation, which led to stagnation of deeper waters. Comparison with the land sections also confirms that differential preservation and diagenesis play a key role in sapropel occurrence.
\end{abstract}

\section{INTRODUCTION}

The primary aim of this paper is to present a standard stable oxygen isotope record for the Eastern Mediterranean for the last $3.2 \mathrm{Ma}$ and to establish a chronology for the sapropels that occur in the sedimentary sequence at Site 967 . Integration of the results of this work with similar studies of sapropel successions from other parts of the Eastern Mediterranean (Leg 160) is a primary paleoceanographic objective of Leg 160 (Emeis, Robertson, Richter, et al., 1996). This paper focuses on the site furthest to the east, Site 967, which is located on the lower northern slopes of the Eratosthenes Seamount (Fig. 1). The data from this site, when combined with that from other sites in the Eastern Mediterranean (Leg 160), shed light on the conditions necessary for coeval sapropel formation across the Eastern Mediterranean, especially the spatial gradients in environmental conditions. In the near future, when more data becomes available for sites in the Western Mediterranean (Leg 161), it should be possible to reconstruct the paleoceanography of sapropel formation for the entire Mediterranean basin, especially the role of circulation patterns that are based on high-resolution studies. This will hopefully result in a better understanding of the climate system that was active during sapropel formation.

Results from Deep Sea Drilling Project sites (Legs 13 and 42A; Ryan, Hsü et al., 1973; Hsü and Montadert, 1978; and Kidd et al., 1978) and studies of geological outcrops in southern Italy, Sicily, and Crete (for recent reviews see Hilgen et al., 1993) reveal that sapropel formation has occurred episodically throughout the Miocene,

'Robertson, A.H.F., Emeis, K.-C., Richter, C., and Camerlenghi, A. (Eds.), 1998. Proc. ODP, Sci. Results, 160: College Station, TX (Ocean Drilling Program).

${ }^{2}$ Department of Geology and Geophysics, Edinburgh University, West Mains Road, Edinburgh, EH9 3JW, United Kingdom. Alastair.Robertson@glg.ed.ac.uk

${ }^{3}$ Department of Geology, Faculty of Earth Sciences, Utrecht University, Utrecht, Netherlands

${ }^{4}$ Institut für Ostseeforschung Warnemunde, Universitat Rostock, Seestrasse 15, D18119 Rostock-Warnemunde, Federal Republic of Germany.
Pliocene, and Pleistocene in the Eastern Mediterranean. The discovery of sapropels in cores from the Tyrrhenian Sea (Ocean Drilling Project Leg 107) showed that formation and preservation of organicrich layers were not restricted to the Eastern Mediterranean basins, and thus the entire Mediterranean basin needs to be considered (Thunell et al., 1990; Emeis et al., 1991).

Early work on Pleistocene sapropels suggested that timing of sapropel formation is related to glacial-interglacial cycles (e.g., Kullenberg, 1952; Olausson, 1961; Ryan, 1972; McCoy, 1974; Ryan and Cita, 1977). Subsequent, more detailed, studies of faunal and floral contents suggest that various Pleistocene sapropels accumulated under different climatic conditions, with the S6 and S8 sapropels having been deposited under relatively cool conditions, while S5 and S7 formed during relatively warm periods (Cita and Grignani, 1982; Rossignol-Strick, 1983, 1985). Early studies also indicate a link between sapropel formation and orbital parameters with distinct correlation between the timing of sapropel formation and minima in the precessional cycle, which occur every 21,000 years (RossignolStrick, 1983 and 1985; Prell and Kutzbach, 1987; Hilgen 1991; Lourens et al., 1996a, 1996b). Monsoonal circulation was thought to intensify over eastern equatorial Africa as a consequence of a minimum in the precessional cycle, which leads to higher precipitation and increased discharge from the Nile into the Eastern Mediterranean. Increased precipitation is also recorded at these times in the northern borderlands of the Eastern Mediterranean (Shaw and Evans, 1984; Rossignol-Strick, 1987; Cramp et al., 1988; and Wijmstra et al., 1990), accompanied by reduced evaporation from Mediterranean surface waters (Rohling and Hilgen, 1991).

There is no widespread deposition of organic-rich layers in the Mediterranean today. This fact implies that Mediterranean circulation operated differently from the modern situation during times of sapropel formation. Bradley (1938), Kullenberg (1952), and Olausson (1961) suggested that deep-water stagnation occurred during times of sapropel formation, making the assumption that the preservation of organic matter is enhanced under anoxic conditions. Depletion of oxygen in deep waters would be the result of termination of 


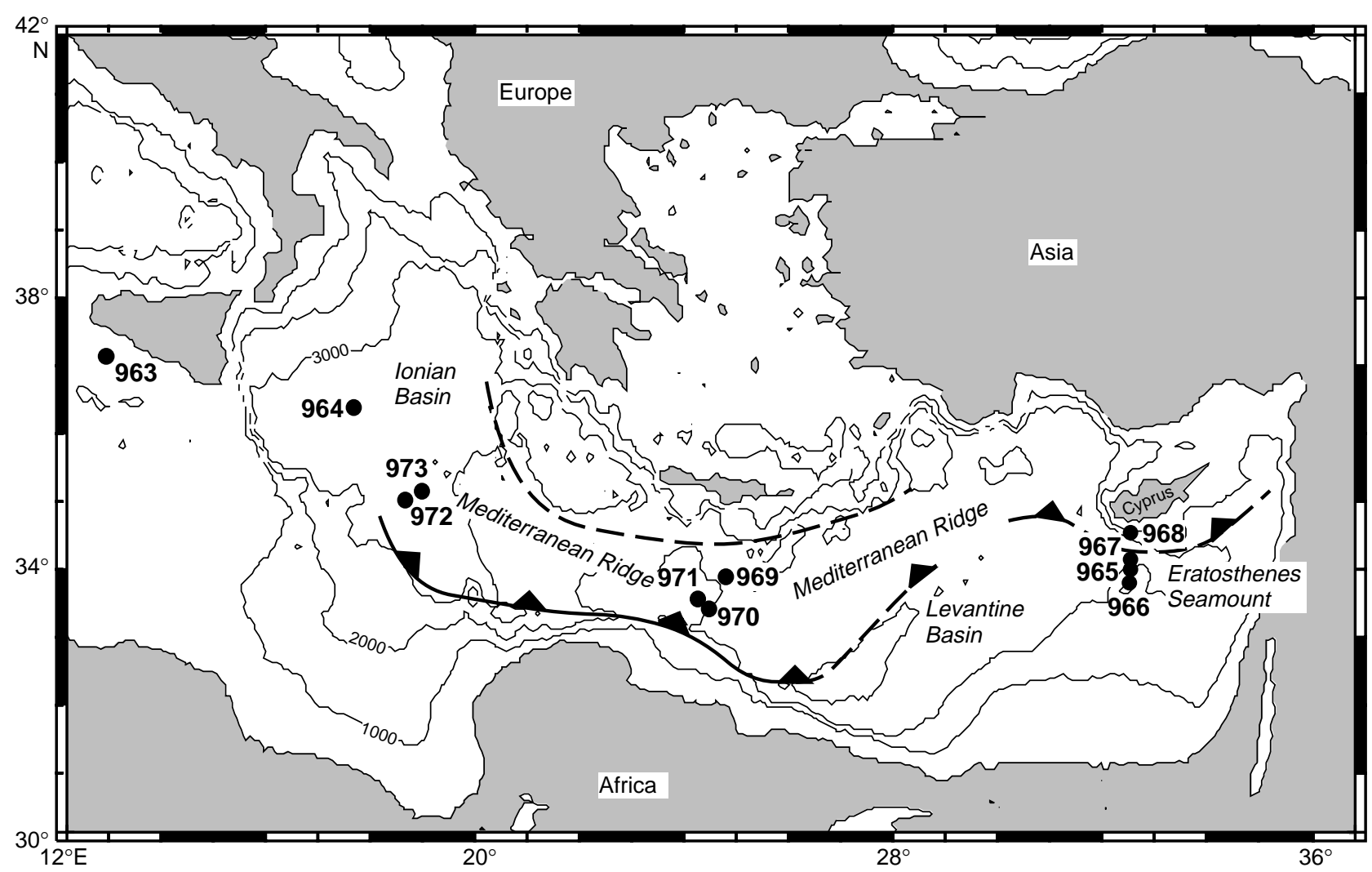

Figure 1. Map showing the location of ODP Leg 160 Site 967 on the lower northern slopes of the Eratosthenes Seamount, Eastern Mediterranean.

thermohaline convective overturn and deep-water ventilation. The strongest support for this model comes from negative oxygen isotope anomalies recorded in planktonic foraminifers that are associated with the sapropels (e.g., Williams et al., 1978, and Vergnaud-Grazzini et al., 1986). Such values are thought to relate to lowered marine salinity in relatively near surface waters where the planktonic foraminifers lived. The negative isotopic anomalies have been interpreted to imply the existence of a low-salinity, and, therefore, low-density, surface layer in the Eastern Mediterranean at the time of sapropel deposition. The presence of a low-density surface layer would inhibit thermohaline circulation. Presumed sources of freshwater input include the Nile River, the Atlantic Ocean, and waters inflowing from the northeastern Mediterranean hinterland, including the Black Sea (Müller, 1990) and more local fluvial input (Shaw and Evans, 1984; Rossignol-Strick, 1987; Cramp et al., 1988; Rohling and Gieskes, 1989; and Wijmstra et al., 1990).

The assumption of deep-water stagnation however, has been strongly questioned as a mechanism for the formation of all the Pliocene-Pleistocene sapropels. Even in localities where anoxic and hypersaline bottom waters prevail today, such as in the Tyro and Bannock basins (Jongsma et al., 1983; De Lange and ten Haven, 1983; Cita et al., 1985; Parisi et al., 1987), the $\mathrm{C}_{\text {org }}$ preservation, although enhanced $\left(1.3 \% \mathrm{C}_{\text {org }}\right)$ relative to elsewhere in the Mediterranean $\left(0.3 \% \mathrm{C}_{\text {org }}\right)$, is still much lower than typical values in the sapropels $(3 \%-17 \%)$ (Calvert, 1983), for example, from Site 967 (Emeis, Robertson, Richter, et al., 1996). It thus seems likely that upwelling, or an alternative source of nutrients, is needed to enhance $\mathrm{C}_{\text {org }}$ production sufficient for sapropels to form (i.e., in the "high-productivity hypothesis"), and that stagnation alone is not sufficient (i.e., the "anoxicity hypothesis"). An exception, however, may be the sapropels with unusually low $\mathrm{C}_{\text {org }}$ content, for example, the Holocene sapropel S1.
Several models have recently been proposed to explain pathways in which productivity levels could have been enhanced in the presently oligotrophic Mediterranean. One long-standing proposal is that reversal of the present anti-estuarine circulation system caused upwelling of nutrient-rich waters, which led to high productivity, thereby increasing the demand for oxygen to combust organic material, resulting in episodic development of anoxia (Sarmiento et al., 1988). Isotopic and geochemical tracers do suggest a predominantly marine origin for the sapropel $\mathrm{C}_{\text {org }}$ content (Sutherland et al., 1984; Smith et al., 1986; ten Haven et al., 1987), which in turn suggests that increased marine productivity rather than merely terrestrial organic matter input was involved.

In addition, the present-day estuarine circulation pattern is in apparent contradiction with $\delta^{13} \mathrm{C}$ signatures from benthic foraminifers that were obtained from sediments cored to the west of the Strait of Gibraltar. This data implies that outflow of deep waters from the Mediterranean to the North Atlantic continued during the formation of sapropel S1 (7-9 ka), although at reduced rates relative to the present (Zahn et al., 1987). Furthermore, while high freshwater input is suggested as the cause of a circulation reversal (Sarmiento et al., 1988), areal mapping of the negative oxygen isotope anomalies observed in sediment cores from around the Nile Cone suggests that the low-salinity layer that existed during the formation of sapropel S1 was strongest in the immediate vicinity of the river mouth, presumably because freshwater mixes rapidly with the highly saline waters of the easternmost Mediterranean (Jenkins and Williams, 1984). Thus, the effects of any enhanced productivity associated with nutrient-rich river water input may have been restricted to the area closest to the Nile. Any stabilizing effect of such a low salinity cap is also likely to have been geographically restricted, so that thermohaline overturn could still have persisted in the Eastern Mediterranean at a 
distance from the Nile delta, including Site 967, which is located well to the north (Fig. 1).

More recently, Rohling and Gieskes (1989) have postulated a causal link between the development of a deep, chlorophyll maximum at the base of the euphotic zone and the formation of sapropels. In their hypothesis, a combination of freshwater input and lowering of the density of the Mediterranean intermediate waters leads to a reduction in deep-water production, thus reducing thermohaline overturn, although not necessarily producing complete stagnation. Lowering the density of the Mediterranean intermediate waters also resulted in the shallowing of the boundary between nutrient-rich deeper waters and depleted surface water. If this boundary shallowed sufficiently to intersect with the base of the euphotic zone it would stimulate primary production of deep phytoplankton at the base of the thermocline and, hence, promote high productivity.

Site 967 is ideally located in the Eastern Mediterranean to study the environmental variables responsible for controlling the formation of sapropels. In particular, it is situated to the north of the Nile delta (Fig. 1) and can thus test the hypothesis of sapropel formation related to increased freshwater input, particularly from the Nile. Specifically, the stable oxygen isotope stratigraphy of Site 967 has the potential to provide documentation of periods of increased freshwater supply throughout the last 3.2 Ma and thus allow a determination of any oxygen isotope anomalies related to sapropel formation.

The aims of this paper are to establish a high resolution chronology for the Pliocene-Pleistocene sequence and to develop a time framework for sapropel stratigraphy. We will also chart any $\delta^{18} \mathrm{O}$ anomalies through time, with the aim of documenting a possible relationship between sapropel formation and surface water conditions. In addition, we will also draw comparisons with isotopic trends in the open ocean and with land-based marine sequences in Italy.

\section{MATERIALS AND METHODS}

Site 967 was drilled on a small ridge that trends west-southwest to east-northeast along the base of the northern slope of the Eratosthenes Seamount in water 2554 mbsl (Fig. 1). Sediments were recovered from five holes, of which four were sampled in the present study (Emeis, Robertson, Richter, et al., 1996). The discovery of well-preserved sapropels at this site was highly fortuitous, as this site was originally included for the purpose of studying the tectonic history of the Eratosthenes Seamount. The sediments consist of bioturbated nannofossil ooze and nannofossil clay intercalated with sapropels. There are also numerous turbidites, but these are relatively thin and fine grained and have not significantly disrupted the sapropel stratigraphy. An interval of deformed sediments of varying thickness occurs in three holes around 55 mbsf. This interval is interpreted as a sediment slide or slump unit. However, the shipboard biostratigraphy indicates that the succession is otherwise complete except for a possible short hiatus that occurs at the end of the late Pliocene (Emeis, Robertson, Richter, et al., 1996).

Stable isotope data from Site 967 was analyzed at the Department of Geology and Geophysics, University of Edinburgh during the late summer of 1996 . The sample spacing was $20 \mathrm{~cm}$ within every hole. Approximately 8 to 10 individuals of Globigerinoides ruber (d'Orbigny) (200-250 mm size fraction) were required to achieve an analytical weight of between 0.05 and $0.10 \mathrm{mg}$. Picked foraminifers were cleaned in an ultrasonic bath prior to stable isotope analysis on a VG Isotech PRISM mass spectrometer equipped with a VG Autocarb common-bath preparation system and microinlet. $\mathrm{CO}_{2}$ was produced by reaction with orthophosphoric acid at $90^{\circ} \mathrm{C}$ and passed through a stainless steel coil water trap maintained at $-80^{\circ} \mathrm{C}$ with a liquid $\mathrm{N}_{2}$ probe. All isotope data are reported as per mil units $(\% \circ)$ relative to the Pee Dee Belemnite (PDB) standard in d notation. The precision for oxygen isotope analysis was $0.08 \%$ (standard deviation for several hundred analyses of a standard carbonate, SM1, with weights of 0.05 to $0.10 \mathrm{mg}$, conducted over several months).

A composite depth model (revised meters composite depth; rmcd) needed to be established for the four holes drilled adjacent to each other. The initial composite depth model was produced on ship by using percent color reflectance and magnetic susceptibility records. Shore-based research by Sakamoto et al. (Chap. 4, this volume) has improved the initial shipboard correlations between the holes and the results show that the four cores from Holes 967A, 967B, 967C and 967D include sufficient overlaps for a continuous composite section to be constructed for Site 967.

\section{RESULTS AND AGE MODEL}

Figure 2 shows the combined isotope data from Site 967 plotted against rmcd. All isotope data are listed in Table 1 (complete table is on CD-ROM, back pocket, this volume). The composite isotope record from $0-125 \mathrm{~m}$ (rmcd) illustrates that the variations within the $\delta^{18} \mathrm{O}$ record of Site 967 all show a larger glacial-interglacial range (up to 5\%o) than in the Atlantic. This is consistent with other planktonic foraminifer records from the Eastern Mediterranean (VergnaudGrazzini et al., 1977). The large amplitudinal variations show that the Eastern Mediterranean was affected by freshwater input throughout the sequence, with the upper part exhibiting the largest variability.

The age model for Site 967 is based on the correlation of the precessionally controlled sedimentary cycles to the precession time series of the astronomical solution for the interval 1 to 3 million years. Early Pleistocene and Pliocene sedimentary cycles in the form of sapropels or carbonate cycles have been successfully used by Hilgen (1991) and Lourens et al. (1996a) to calibrate Mediterranean marine sequences. The chronology is based on the assumption that the timing of sapropel formation is mainly precessionally controlled. For details of the method the reader is referred to Lourens et al. (1996a) and Lourens et al. (Chap. 15, this volume, for the interval 1.2 to $2 \mathrm{Ma}$ ). The age model for the last million years is established by a combination of astronomical calibration of the sapropel record in the form of the color reflectance cycles and the stable oxygen isotope stratigraphy. The color reflectance record does not show such a distinct cyclicity pattern for the last million years, as it does for the period 1 to 3 million years, and the $\delta^{18} \mathrm{O}$ record was helpful to establish a solid age frame work. All age tie lines either to the astronomical target curve or to the established $\delta^{18} \mathrm{O}$ record of Mix et al. (1995) are given in Table 2 (also on CD-ROM, back pocket, this volume).

To study the $\delta^{18} \mathrm{O}$ anomalies that may reveal the surface water conditions in the Eastern Mediterranean we need to compare the $\delta^{18} \mathrm{O}$ variations from Site 967 with the $\delta^{18} \mathrm{O}$ fluctuations observed in a deep-sea benthic $\delta^{18} \mathrm{O}$ record that mainly demonstrates ice volume variations. We have chosen the benthic $\delta^{18} \mathrm{O}$ record from ODP Pacific Site 849 as the detailed age model was developed by tuning to other records for the upper $2.5 \mathrm{Ma}$, and directly to astronomical cycles for the interval 2.5 to $4 \mathrm{Ma}$ (Mix et al., 1995). The stable oxygen isotope records from Sites 967 and 849 are shown as a function of age in Figure 3. In general, an excellent match is achieved for the last 3.2 Ma. Almost all isotope stages recognized by Shackleton et al. (1990) and Tiedemann et al. (1994) can be identified at Site 967. An increase in the $\delta^{18} \mathrm{O}$ amplitude over this time period in relation to the development of a 100 k.y. cyclicity can be seen clearly (Fig. 3).

The shipboard paleomagnetic reversal record for Site 967 is not useful (Emeis, Robertson, Richter, et al., 1996) and thus the nannofossil stratigraphy is the only tool effective to obtain additional datum levels of chronological significance. Nannofossil datum levels are reported in Staerker (Chap. 7, this volume) and are plotted in Figure 2. The nannofossil events are reasonably consistent with the age model 
Figure 2. The stable oxygen isotope record for Site 967 plotted against depth (rmcd). The rmcd was constructed by Sakamoto et al. (Chap. 4, this volume). Nannofossil events are from Staerker (Chap. 7, this volume). $\mathrm{FAD}=$ first appearance datum; $\mathrm{LAD}=$ last appearance datum; $\mathrm{LCO}=$ last common occurrence

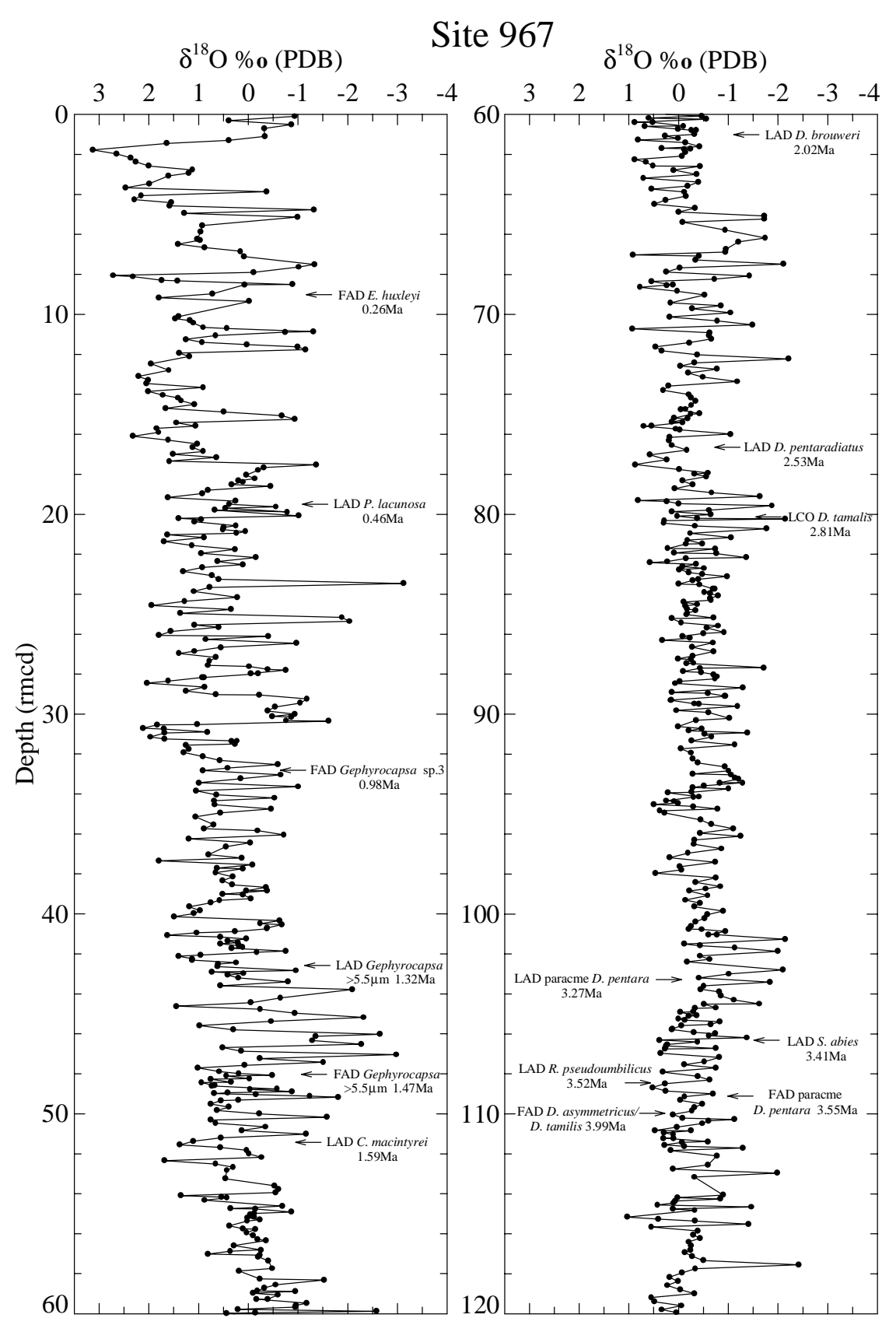

Table 1. Isotopic data for samples analyzed from Site 967.

\begin{tabular}{|c|c|c|c|c|}
\hline $\begin{array}{l}\text { Core, section, } \\
\text { interval } \\
(\mathrm{cm})\end{array}$ & $\begin{array}{l}\text { Depth } \\
\text { (mbsf) }\end{array}$ & $\begin{array}{l}\text { Depth } \\
\text { (rmcd) }\end{array}$ & $\begin{array}{l}\delta^{18} \mathrm{O} \% o \\
(\mathrm{PDB})\end{array}$ & $\begin{array}{l}\text { Age } \\
\text { (Ma) }\end{array}$ \\
\hline \multicolumn{5}{|l|}{ 160-967A- } \\
\hline $1 \mathrm{H}-5,10-12$ & 6.10 & 6.09 & & 0.1090 \\
\hline $1 \mathrm{H}-5,30-32$ & 6.30 & 6.28 & 0.98 & 0.1119 \\
\hline $1 \mathrm{H}-5,48-50$ & 6.48 & 6.46 & & 0.1129 \\
\hline $1 \mathrm{H}-5,68-70$ & 6.68 & 6.66 & 0.88 & 0.1147 \\
\hline $1 \mathrm{H}-5,90-92$ & 6.90 & 6.85 & 0.16 & 0.1166 \\
\hline $1 \mathrm{H}-5,110-112$ & 7.10 & 7.10 & 0.09 & 0.1192 \\
\hline $1 \mathrm{H}-5,130-132$ & 7.30 & 7.32 & & 0.1213 \\
\hline 1H-5, 146-148 & 7.46 & 7.51 & -1.33 & 0.1232 \\
\hline $1 \mathrm{H}-6,10-12$ & 7.60 & 7.63 & -1.01 & 0.1251 \\
\hline $1 \mathrm{H}-6,34-36$ & 7.84 & 7.90 & -0.11 & 0.1312 \\
\hline
\end{tabular}

Note: Analytical procedures and sampling intervals are discussed in the text.

Only part of this table is produced here. The entire table appears on CD-ROM (back pocket). based on tuning and the stable isotope record although there are exceptions for the early Pleistocene in Site 967. The first occurrence of large Gephyrocapsa appears to be slightly older (1.61 Ma) than reported in the Atlantic records (for a more detailed discussion see Lourens et al., Chap. 15, this volume).

\section{SAPROPEL CHRONOLOGY}

Eighty sapropels were recognized by the Shipboard Scientific Party and a tentative correlation of the four holes was made (Emeis, Robertson, Richter, et al., 1996). Sakamoto et al. (Chap. 4, this volume) then revised the position of the sapropels with respect to composite depth (rmcd; Table 2). The ages of the sapropels (mid-depths) derived from our age model are given in Table 2.

The ages of the upper twelve, well-preserved, sapropels at Site 967 are taken as the well-known and dated Mediterranean sapropels 
Table 2. Sapropel and age model data for Site 967.

\begin{tabular}{|c|c|c|c|c|c|c|}
\hline $\begin{array}{l}\text { Sapropel } \\
\text { code }\end{array}$ & $\begin{array}{c}\text { Composite } \\
\text { depth } \\
\text { (rmcd) }\end{array}$ & $\begin{array}{c}\text { Sapropel } \\
\text { age } \\
\text { (Ma) }\end{array}$ & $\begin{array}{c}\text { * Site } 849 \\
\text { age } \\
\text { (Ma) }\end{array}$ & $\begin{array}{c}\text { Site } 967 \\
\text { age } \\
(\mathrm{Ma})\end{array}$ & $\begin{array}{c}* * \text { Italian } \\
\text { sections }\end{array}$ & i-cycle \\
\hline \multirow[t]{2}{*}{1} & 1.190 & 0.008 & \multirow{6}{*}{0.016} & 0.008 & S1 & 2 \\
\hline & 1.780 & & & 0.016 & & \\
\hline a & 2.859 & 0.055 & & 0.055 & $\mathrm{~S} 2$ & 6 \\
\hline 2 & 4.265 & 0.081 & & 0.081 & S3 & 8 \\
\hline $3 / 4$ & 5.398 & 0.102 & & 0.102 & S4 & 10 \\
\hline \multirow[t]{3}{*}{5} & 7.585 & 0.124 & & 0.124 & S5 & 12 \\
\hline & 8.110 & & 0.136 & 0.136 & & \\
\hline & 9.160 & & 0.160 & 0.160 & & \\
\hline 6 & 9.625 & 0.172 & & 0.172 & S6 & 16 \\
\hline 7 & 10.790 & 0.195 & & 0.195 & S7 & 18 \\
\hline 8 & 11.680 & 0.217 & & 0.217 & S8 & 20 \\
\hline \multirow[t]{3}{*}{9} & 12.208 & 0.240 & & 0.240 & S9 & 22 \\
\hline & 13.100 & & 0.268 & 0.268 & & \\
\hline & 13.660 & & 0.288 & 0.288 & & \\
\hline \multirow[t]{2}{*}{10} & 15.050 & 0.331 & & 0.331 & $\mathrm{~S} 10$ & 30 \\
\hline & 15.990 & & 0.348 & 0.348 & & \\
\hline \multirow[t]{2}{*}{ b } & 18.005 & 0.407 & & 0.407 & S11 & 38 \\
\hline & 19.120 & & 0.440 & 0.440 & & \\
\hline 11 & 20.015 & 0.483 & & 0.483 & $\mathrm{~S} 12$ & 46 \\
\hline 12 & 20.850 & 0.503 & & 0.503 & & 48 \\
\hline \multirow{3}{*}{13} & 21.230 & 0.526 & & 0.526 & & 50 \\
\hline & 21.840 & & 0.552 & 0.552 & & \\
\hline & 22.360 & & 0.575 & 0.575 & & \\
\hline 14 & 22.915 & 0.598 & & 0.598 & & 56 \\
\hline 15 & 23.505 & 0.620 & & 0.620 & & 58 \\
\hline $\mathrm{c}$ & 24.115 & 0.641 & & 0.641 & & 60 \\
\hline 16 & 25.285 & 0.668 & & 0.668 & & 62 \\
\hline \multirow[t]{7}{*}{17} & 25.850 & 0.690 & & 0.690 & & 64 \\
\hline & 26.890 & & 0.720 & 0.720 & & \\
\hline & 27.760 & & 0.784 & 0.784 & & \\
\hline & 28.440 & & 0.796 & 0.796 & & \\
\hline & 30.550 & & 0.872 & 0.872 & & \\
\hline & 31.400 & & 0.892 & 0.892 & & \\
\hline & 31.750 & & 0.916 & 0.916 & & \\
\hline 18 & 32.605 & 0.934 & & 0.934 & & 88 \\
\hline 19 & 33.155 & 0.955 & & 0.955 & & 90 \\
\hline 20 & 33.790 & 0.976 & & 0.976 & & 92 \\
\hline 21 & 34.150 & 0.997 & & 0.997 & & 94 \\
\hline 22 & 34.870 & 1.027 & & 1.027 & & 96 \\
\hline 23 & 35.485 & 1.048 & & 1.048 & & 98 \\
\hline 24 & 35.950 & 1.070 & & 1.070 & & 100 \\
\hline 25 & 36.430 & 1.091 & & 1.091 & & 102 \\
\hline 26 & 37.056 & 1.111 & & 1.111 & & 104 \\
\hline 27 & 38.610 & 1.164 & & 1.164 & & 110 \\
\hline 28 & 39.240 & 1.185 & & 1.185 & & 112 \\
\hline 29 & 41.847 & 1.280 & & 1.280 & $\mathrm{v}$ & 122 \\
\hline 30 & 42.776 & 1.315 & & 1.315 & $\mathrm{u}$ & 126 \\
\hline 31 & 43.320 & 1.335 & & 1.335 & & \\
\hline 32 & 43.945 & 1.356 & & 1.356 & $\mathrm{t}$ & 130 \\
\hline 33 & 44.560 & 1.376 & & 1.376 & & \\
\hline 34 & 45.120 & 1.398 & & 1.398 & $*$ & 134 \\
\hline 35 & 45.953 & 1.429 & & 1.429 & $\mathrm{~s}$ & 138 \\
\hline 36 & 46.538 & 1.449 & & 1.449 & $r$ & 140 \\
\hline 37 & 47.000 & 1.471 & & 1.471 & $\mathrm{C} 13, \mathrm{q}$ & 142 \\
\hline 38 & 49.150 & 1.564 & & 1.564 & $\mathrm{C} 12, \mathrm{p}$ & 152 \\
\hline 39 & 49.699 & 1.584 & & 1.584 & & \\
\hline
\end{tabular}

\begin{tabular}{|c|c|c|c|c|c|c|}
\hline $\begin{array}{l}\text { Sapropel } \\
\text { code }\end{array}$ & $\begin{array}{c}\text { Composite } \\
\text { depth } \\
\text { (rmcd) }\end{array}$ & $\begin{array}{c}\text { Sapropel } \\
\text { age } \\
\text { (Ma) }\end{array}$ & $\begin{array}{c}* \text { Site } 849 \\
\text { age } \\
\text { (Ma) }\end{array}$ & $\begin{array}{c}\text { Site } 967 \\
\text { age } \\
(\mathrm{Ma})\end{array}$ & $\begin{array}{c}* * \text { Italian } \\
\text { sections }\end{array}$ & i-cycle \\
\hline 40 & 50.080 & 1.603 & & 1.603 & $\mathrm{C} 11, \mathrm{o}$ & 156 \\
\hline 41 & 50.575 & 1.622 & & 1.622 & & 158 \\
\hline 42 & 51.025 & 1.642 & & 1.642 & $\mathrm{C} 10, \mathrm{n}$ & 160 \\
\hline 43 & 52.185 & 1.694 & & 1.694 & & 166 \\
\hline 44 & 52.590 & 1.715 & & 1.715 & C9, h & 168 \\
\hline 45 & 53.005 & 1.736 & & 1.736 & $\mathrm{C} 8, \mathrm{f}$ & \\
\hline 46 & 53.405 & 1.757 & & 1.757 & C7, * & 172 \\
\hline 47 & 54.570 & 1.808 & & 1.808 & C6, e & 176 \\
\hline 48 & 55.075 & 1.829 & & 1.829 & $\mathrm{C} 5, \mathrm{~d}$ & 178 \\
\hline 49 & 55.605 & 1.851 & & 1.851 & $\mathrm{C} 4, \mathrm{c}$ & 180 \\
\hline 50 & 56.065 & 1.872 & & 1.872 & $\mathrm{C} 3, \mathrm{~b}$ & 182 \\
\hline $\mathrm{d}$ & 56.675 & 1.900 & & 1.900 & & 184 \\
\hline 51 & 57.225 & 1.923 & & 1.923 & $\mathrm{C} 2, \mathrm{a}$ & 186 \\
\hline 52 & 57.776 & 1.944 & & 1.944 & $\mathrm{C} 1$ & 188 \\
\hline I & 59.094 & slump & & slump & & \\
\hline g & 59.566 & slump & & slump & & \\
\hline 53 & 66.997 & 2.094 & & 2.094 & B7 & 204 \\
\hline 54 & 67.485 & 2.115 & & 2.115 & B6 & \\
\hline 55 & 68.120 & 2.137 & & 2.137 & B5 & 208 \\
\hline 56 & 69.187 & 1.285 & & 1.285 & B4 & 212 \\
\hline 57 & 69.815 & 2.208 & & 2.208 & B3 & 214 \\
\hline 58 & 70.465 & 2.229 & & 2.229 & B2 & 216 \\
\hline 59 & 70.975 & 2.252 & & 2.252 & $\mathrm{BX}$ & 218 \\
\hline 60 & 72.206 & 2.301 & & 2.301 & B1 & 222 \\
\hline 61 & 73.329 & 2.344 & & 2.344 & & 226 \\
\hline 62 & 79.021 & 2.588 & & 2.588 & A5 & 250 \\
\hline 63 & 79.561 & 2.611 & & 2.611 & A $4 / 5$ & 252 \\
\hline 64 & 80.145 & 2.632 & & 2.632 & A4 & 254 \\
\hline 65 & 80.710 & 2.658 & & 2.658 & A3 & 256 \\
\hline 66 & 81.375 & 2.679 & & 2.679 & A2 & 258 \\
\hline 67 & 82.100 & 2.703 & & 2.703 & A1 & 260 \\
\hline 68 & 84.870 & 2.828 & & 2.828 & 111 & 272 \\
\hline 69 & 85.820 & 2.871 & & 2.871 & 110 & 276 \\
\hline 70 & 86.550 & 2.900 & & 2.900 & 109 & 278 \\
\hline 71 & 87.050 & 2.921 & & 2.921 & 108 & 280 \\
\hline 72 & 87.570 & 2.943 & & 2.943 & 107 & 282 \\
\hline 73 & 88.070 & 2.965 & & 2.965 & 106 & 284 \\
\hline 74 & 88.584 & 2.989 & & 2.989 & 105 & 286 \\
\hline 75 & 89.130 & 3.014 & & 3.014 & 104 & 288 \\
\hline 76 & 89.650 & 3.036 & & 3.036 & 103 & 290 \\
\hline 77 & 90.000 & 3.058 & & 3.058 & 102 & 292 \\
\hline 78 & 90.376 & 3.080 & & 3.080 & 101 & 294 \\
\hline 79 & 90.925 & 3.105 & & 3.105 & 100 & 296 \\
\hline 80 & 92.075 & 3.151 & & 3.151 & 98 & 300 \\
\hline
\end{tabular}

Notes: The table shows age tie-lines by astronomical calibration of the color reflectance record (and thus the sapropels). The mid-depths of the sapropels were taken for the age tie-lines. A 3-k.y. precession lag was assumed, based on the age difference between the youngest Holocene sapropel S1 and the correlative precession minimum. The user is referred to Lourens et al. (1996) for details of the tuning method. A correlation is made with the assigned ages of sapropels observed in the southern Italian land section. $*$ = the Pacific Site $849 \delta^{18}$ O record (Mix et al., 1984) was used to produce additional age tie-lines for the last $1 \mathrm{~m} . \mathrm{y} . * *=$ The Italian sections are Punta Piccola, Sicily (Italy), Vrica, and Singa, Calabria (Italy) (see Lourens et al., 1996a, 1996b).

(S1-S12). This is corroborated by the stable oxygen isotope stratigraphy. The ages of sapropels $12-28$ in the interval from 0.5 to $1.2 \mathrm{Ma}$ are quite well constrained and are considered to be reliable. Sapropels 29-42 form a cluster in the interval from 1.25 to $1.65 \mathrm{Ma}$. This group of sapropels correlates well with the cluster of sapropels observed and dated in the Vrica and Crotone sections (Lourens et al., 1996a). Lourens et al. (1996b) discussed two options for the ages of this cluster of sapropels $(v-n)$, as there are discrepancies with the Mediterranean nannofossil event ages with respect to the ages in the open Atlantic in this interval. Option one assumes that the section is continuous, while option two inserts a large hiatus in the Vrica and Crotone sections, which is based on the assumption that the first occurrence of large Gephyrocapsa in the Mediterranean is contemporaneous with the first occurrence in the Atlantic, within oxygen isotope stage 48 (1.475 Ma), as found at DSDP Site 607. The age of 1.61 Ma for the base of large Gephyrocapsa at Site 967, based on the astronomically calibrated time scale, supports the continuous-age model. Using this result, a perfect match can then be achieved between the Site 967 sapropels and the Vrica/Crotone sapropels, and there is no need for a hiatus, as in option two. The highest occurrence of large Gephyrocap$s a$ at $1.32 \mathrm{Ma}$ (Staerker, Chap. 7, this volume) is also consistent with the continuous sedimentation option. Sapropels 31 and 33 do not ap-

pear to have any equivalent in the Vrica and Crotone sections. Sapropel cluster 38-42 correlates perfectly with a group of sapropels in the Vrica/Crotone sections (p-o-n); also, two additional sapropels $(39,41)$ were found at Site 967 within this interval.

Sapropels 43-52, within the interval from 1.7 to $2 \mathrm{Ma}$, can be correlated with three sapropel clusters in the Vrica/Crotone sections. Below this interval, a heavily disturbed unit (1.95 to $2.10 \mathrm{Ma}$ ) is encountered at Site 967 (Emeis, Robertson, Richter, et al., 1996) and thus correlations become unreliable. Site 967 sapropels 53-80 in the interval 2 to $3.2 \mathrm{Ma}$ are correlated to the Vrica/Crotone sapropels (Table 2).

\section{MODES OF SAPROPEL FORMATION}

The stable isotope data presented here provide additional evidence that many, if not most, periods of sapropel formation correspond to times of increased freshwater input (i.e., the negative isotope excursions; Fig. 3). For example, there is a notably high influx at around 1.45 Ma (Fig. 3). Many of the excursions are enhanced relative to equivalent negative excursions for the open Atlantic and $\mathrm{Pa}-$ cific (Fig. 3). The negative isotope anomalies highlight the probable 
Figure 3. Oxygen isotope records from ODP Sites 967 and 849 vs. age (Ma). The Site 849 data are from Mix et al. (1995). The bold line represents the Site 967 oxygen isotope stratigraphy and the thinner line the Site 849 oxygen isotope profile. Oxygen isotope stages are after Shackleton et al. (1990) and Tiedemann et al. (1994). Sapropel stratigraphy is provided by Emeis, Robertson, Richter, et al. (1996); note that the sapropels are not drawn to scale and their position is given relative to their mid-depths. Ghosts of sapropels are indicated as hatched horizons. The planktonic $\delta^{18} \mathrm{O}$ record of Site 967 was adjusted to the benthic $\delta^{18} \mathrm{O}$ record of Pacific Site 849 by adding 3\%o to facilitate a comparison. The figure shows that the $\delta^{18} \mathrm{O}$ variations within the Site 967 record are much larger than in the deep ocean record of Site 849 . The Site 967 record points to prominent $\delta^{18} \mathrm{O}$ surface seawater changes in the eastern Mediterranean, mainly caused by freshwater input during warm periods (assuming that the Pacific deep ocean site mainly documents ice volume changes). The $\delta^{18} \mathrm{O}$ anomalies, in the Site 967 record, point to systematic variations in temperature and the $\delta^{18} \mathrm{O}$ of the surface seawaters with distinct periods (see Fig. 4).

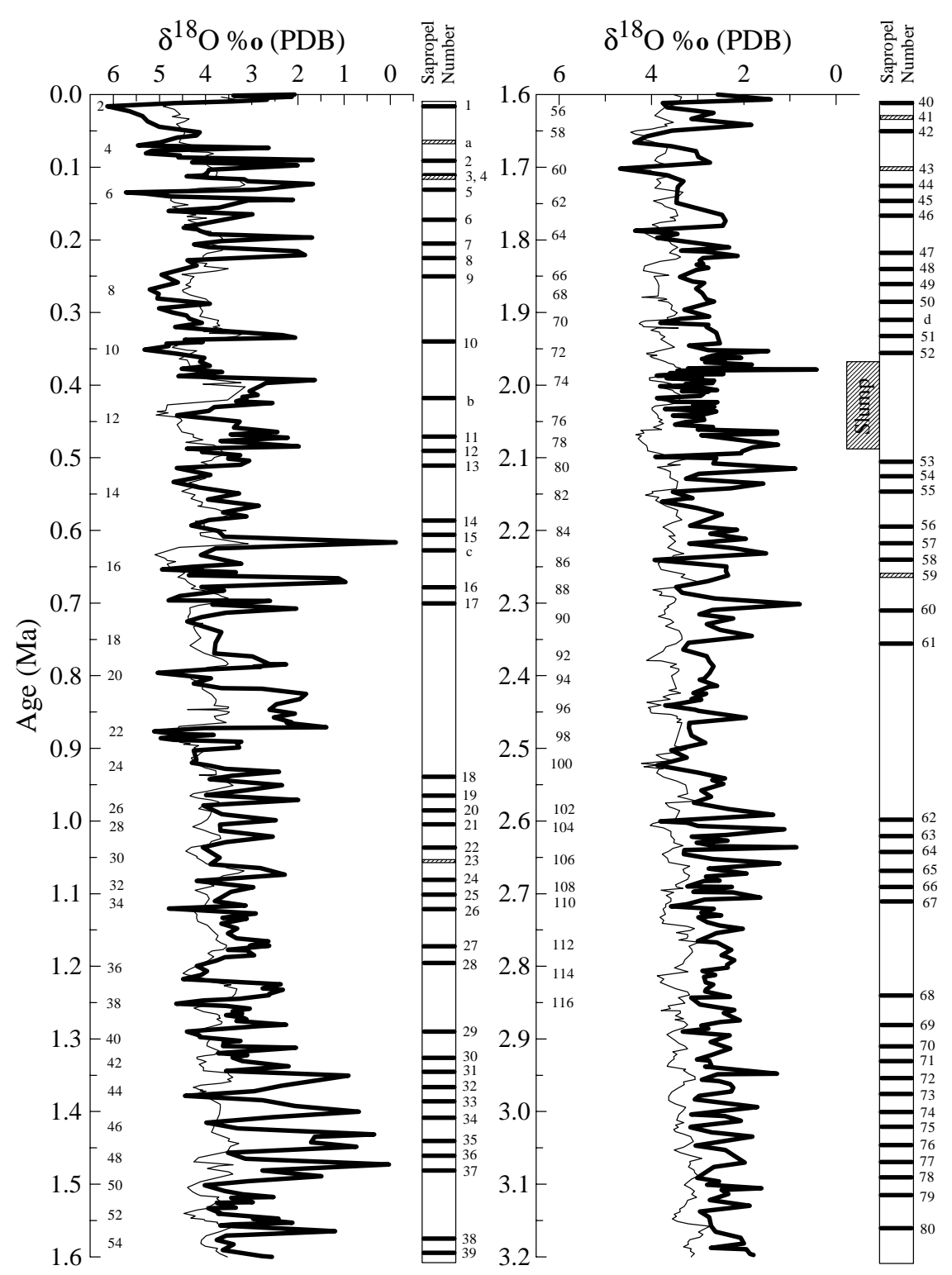

role of freshwater input in sapropel formation in the Eastern Mediterranean basin relative to the open ocean. The magnitude of salinity changes during sapropel formation is discussed in Emeis et al., (Chap. 26, this volume). The results could be interpreted as indicative of a direct, or as only an indirect link with sapropel formation. In the option of a direct link, periods of inferred large-scale influx of freshwater, corresponding to relatively warm periods, could have given rise to a low-salinity cap that impeded circulation, and led to stagnation of bottom waters and thus sapropel formation. In the more probable indirect link option, the boundary between nutrient-rich Mediterranean intermediate waters and depleted surface waters might have risen, promoting enhanced productivity during the periods of freshwater input, as proposed by Rohling and Gieskes (1989). More information is needed to test these ideas. Also, the high levels of organic carbon $(3 \%-17 \%)$ seem unlikely to have been achieved without either upwelling, or some other source of nutrients (Calvert, 1983).

Comparison of comparable isotope data for other ODP Leg 160 and 161 sites is now needed to provide a better assessment of the relative sources of freshwater input (e.g., Nile vs. Black Sea) in relation to sapropel development. The available information includes isotope data from Sites 963 and 964 in the central Mediterranean (Howell et al., Chap. 13, this volume). It is likely that freshwater would have mixed with normal seawater away from areas of freshwater input rather than spreading out as a continuous cap capable of modifying density structure. Similar age models, however, need to be constructed for all sites to make a meaningful comparison.

\section{EASTERN MEDITERRANEAN CLIMATE}

Spectral analysis of the Site $967 \delta^{18} \mathrm{O}$ record is used to investigate how freshwater influx into the Eastern Mediterranean has varied with orbital forcing for the last $3.2 \mathrm{Ma}$. The precessional cycles exert a particular control over the monsoon, while the obliquity cycles predominantly affect high-latitude climate (Hilgen, 1991). Site 967 is located in a critical area where interference of precessional and obliquity cycles is expected to be marked.

The influence of the astronomical precessional cycle is very strongly expressed in the formation of the late Pliocene and early Pleistocene sapropel cycles. This relates to the fact that the Eastern Mediterranean area is strongly influenced by monsoonal climates and 
rainfall along its borders (Rossignol-Strick, 1983, 1987; Hilgen, 1987; Rohling and Hilgen, 1991 and Hilgen et al., 1993). We generated three power spectra based on the Site $967 \delta^{18} \mathrm{O}$ times series (Fig. 4) with distinct time intervals of a million years. All spectral diagrams show significant spectral power centered on the 23 ka period. Freshwater influx appears to be strongly influenced by monsoonal precessional cycles confirming a solid relationship between sapropel formation and freshwater influx (most likely from the Nile) over the entire 3.2 million years.

Not only does the $\delta^{18} \mathrm{O}$ record of Site 967 document the precessional influence on Eastern Mediterranean climate, but also the obliquity cycle is clearly visible in all three time windows. Obliquity induced climate variations as revealed in the $\delta^{18} \mathrm{O}$ proxy record are particularly clear in the intervals from 1-1.9 and 2.1-3.2 Ma. The $40 \mathrm{ka}$ periodicity is highly significant, confirming that the Eastern Mediterranean climate mimics global climate change (Ruddiman et al., 1989; Raymo et al., 1989; Shackleton et al., 1990; deMenocal et al., 1993 and Tiedemann et al., 1994). The build-up of northern hemisphere ice sheets in the late Pliocene left their signature of glacial climate cycles with a dominant $41 \mathrm{ka}$ period of variation. The obliquity cycle is extremely dominant in the interval from 1-1.9 Ma in the eastern Mediterranean, which seems to relate to the intensification of high latitude glacial-interglacial cycles. This is remarkable as the age model for Site 967 was not constructed based on obliquity cycles but it was constructed exclusively by using the precessionally induced sapropel cycles. This was also found by Hilgen et al. (1993) and Lourens et al. (1996a) by analyzing the frequencies of change in $\delta^{18} \mathrm{O}$ records from the central Mediterranean. Another shift towards the eccentricity cycle occurred during the last million years. The last million years of eastern climate variations share the worldwide climate fluctuations in that they are controlled by eccentricity, obliquity, and precessional related orbital fluctuations.

\section{CONCLUSIONS}

Stable oxygen isotope analyses measured in correlated cores from Site 967 on the lower northern slopes of the Eratosthenes Seamount provide a near-continuous record of eastern Mediterranean surface water conditions during the last 3.2 million years. A high-resolution stratigraphy and age model for the Pliocene-Pleistocene is mainly established by tuning the sapropel pattern to the precession time series of the astronomical solution for the interval 2-3.2 Ma. In addition, stable isotope stratigraphy aided to the age model for the last million years. The age model supports the model of continuous, as opposed to discontinuous deposition (see also Lourens et al., 1996a and Chap. 15 , this volume). No major depositional hiatus need thus be present in the early Pleistocene. The age model also supports the suggestion that the base of Gephyrocapsa in the Eastern Mediterranean is significantly older than in the open ocean.

Assigned ages fit well with ages determined for sapropels in Calabria (Rosella, Singa, and Vrica), as determined using astronomical tuning. Several additional points emerge from a comparison of our data with that from the land sections in Calabria. Assuming the most recent astronomical tuning of the land sapropels is correct (Lourens et al., 1996a), then a number of sapropels are present at Site 967 that appear to be missing in the Vrica/Crotone sections, especially for the early Pleistocene interval. In some intervals where sapropels are present at Site 967, there are only "ghosts" in the land-based sections. This strengthens the argument that the ghosts are indeed remnants of originally well-developed sapropels and highlights the role of diagenesis in the preservation of sapropels.

Spectral analysis of the $\delta^{18} \mathrm{O}$ record shows that global climate fluctuations exerted an important influence on circum-eastern Mediterranean climate. The obliquity-induced climatic variations are surprisingly clear from 1 to $1.9 \mathrm{Ma}$. Further progress can in future be achieved by:

1. Cross-spectral comparisons with other climatic proxies (i.e., sea-surface temperatures [SST]; Emeis et al., Chap. 26, this volume); Cross-spectral analysis with global climate proxies to observe phase leads and lags in the Eastern Mediterranean climate system (e.g., Lourens et al., 1996a).

2. Comparisons of isotopic data for planktonic and benthic foraminifers to compare the role of reduced salinities of surface, as opposed to bottom waters;
Figure 4. Age-depth relationship for Site 967 with iterative spectral analysis results on the Site $967 \delta^{18} \mathrm{O}$ times series. Sedimentation rates were merely constant at Site 967 except for the last $150 \mathrm{ka}$ and around $2 \mathrm{Ma}$ (slumped interval) when sedimentation rates were slightly higher. Spectral analysis results: (1) Period 0-1 Ma: sample time interval $(\mathrm{t})=4$ k.y.; number of samples $(\mathrm{N})=250$; confidence interval (CI) is shown for 60 lags (N/4); (2) Period 1-2 Ma: $\mathrm{t}=4$ k.y.; $\mathrm{N}=250$, CI for 60 lags; Period 2-3.2 Ma: $\mathrm{t}=4$ k.y., $\mathrm{N}=301$; CI for 60 lags. The $80 \%$ and $95 \%$ confidence levels are shown with respect to a second-order polynomial representing the background spectral periodicity. Dominant spectral power is indicated with the period of cyclicity (k.y.). All three time windows show that Eastern Mediterranean climate was strongly influenced by changes at the beat of global climate controlled by Milankovitch periodicities. This is particularly true for the $40 \mathrm{ka}$ and $100 \mathrm{ka}$ periodicities because the record was exclusively tuned by matching the color cycles to astronomical precession cycles. The strong power at the 40 ka periodicity (particularly from 1-2 Ma) indicates that the eastern Mediterranean climate was considerably affected by changes in northern hemisphere climate, when Arctic ice sheets expanded rapidly.

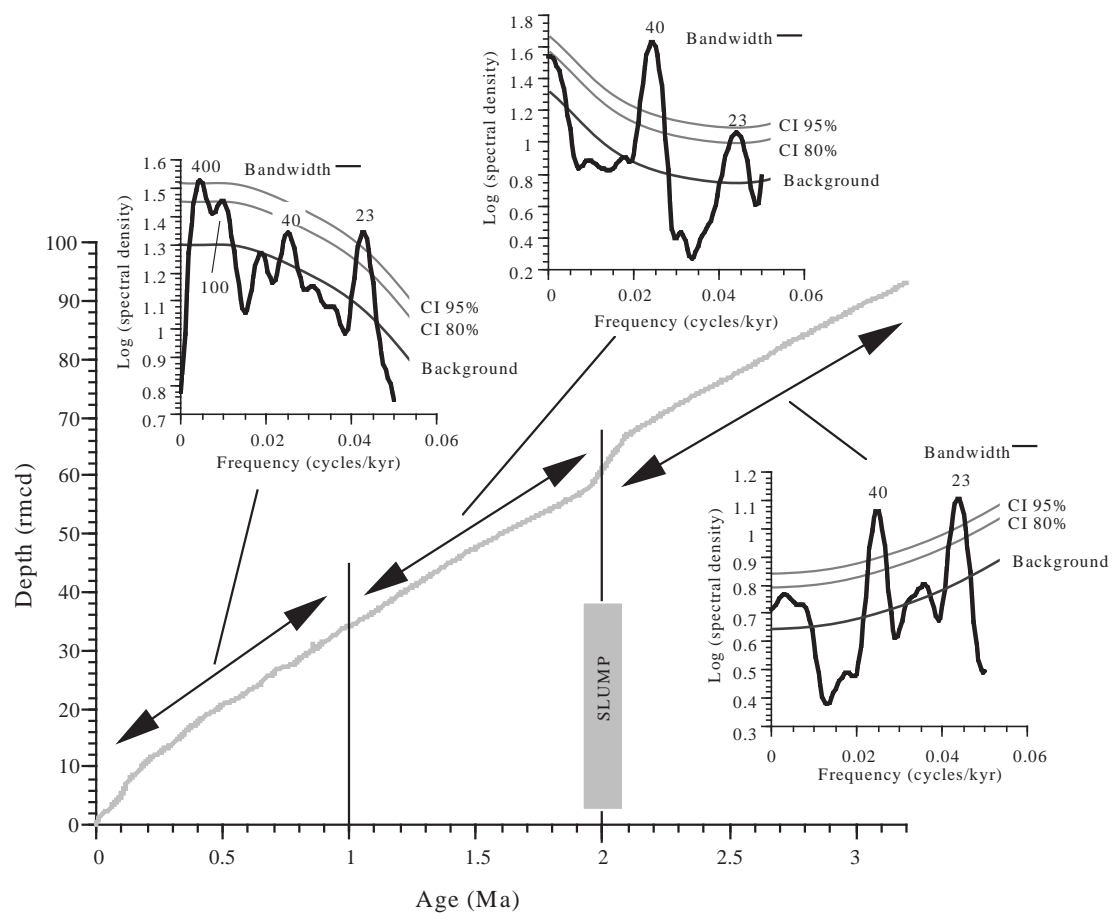


3. Comparison of the isotopic records of warm vs. cool water planktonic foraminifers in relation to SST data;

4. Correlation of the isotopic data with color reflectance and compositional data (e.g., Sakamoto et al., Chap. 4, this volume); and

5. Specific comparison of key time intervals with the neighboring Site 966 on the crest of the Eratosthenes Seamount where sapropel accumulation took place in considerably shallower water and where sapropels are generally less well preserved, despite increased proximity to the Nile (Emeis, Robertson, Richter, et al., 1996).

\section{ACKNOWLEDGMENTS}

This work was supported by a NERC research grant to A.H.F. Robertson and D. Kroon (GST/02/1229). We thank Colin Chilcott for maintenance of the mass spectrometer at the Department of Geology and Geophysics in Edinburgh. Without his help we would not have been able to generate the stable isotope data. We thank Torsten Bickert and Karen Billups for carefully reading the manuscript and improving it. We thank Rachel Flecker for processing the samples and picking the planktonic foraminifers for $\delta^{18} \mathrm{O}$ analysis.

\section{REFERENCES}

Bradley, A.L., 1938. Mediterranean sediments and Pleistocene sea levels. Science, 88:376-379.

Calvert, S.E., 1983. Geochemistry of Pleistocene sapropels and associated sediments from the Eastern Mediterranean. Oceanol. Acta, 6:225-267.

Cita, M.B., and Grignani, D., 1982. Nature and origin of Late Neogene Mediterranean sapropels. In Schlanger, S.O., and Cita, M.B. (Eds.), Nature and Origin of Cretaceous Carbon-rich Facies: London (Academic Press), 165-196.

Cita, M.B., Kastens, K.A., McCoy, F.W., Aghib, F., Cambi, A., Camerlenghi, A., Corselli, C., Erba, E., Giambastiani, M., Herbert, T., Leoni, C., Malinverno, P., Nosetto, A., and Parisi, E., 1985. Gypsum precipitation from cold brines in an anoxic basin in the eastern Mediterranean. Nature, 314:152-154.

Cramp, A., Collins, M.B., and West, R., 1988. Late Pleistocene-Holocene sedimentation in the NW Aegean Sea: a palaeoclimatic palaeoceanographic reconstruction. Palaeogeogr., Palaeoclimatol., Palaeoecol., 68:61-77.

De Lange, G.J., and ten Haven, H.L., 1983. Recent sapropel formation in the Eastern Mediterranean. Nature, 305:797-798.

deMenocal, P.B., Ruddiman, W.F., and Pokras, E.M., 1993. Influence of high- and low-latitude on African terrestrial climate: Pleistocene eolian records from equatorial Atlantic Ocean Drilling Program Site 663. Paleoceanography, 8:209-242.

Emeis, K.-C., Camerlenghi, A., McKenzie, J.A., Rio, D., and Sprovieri, R., 1991. The occurrence and significance of Pleistocene and Upper Pliocene sapropels in the Tyrrhenian Sea. Mar. Geol., 100:155-182.

Emeis, K.-C., Robertson, A.H.F., Richter, C., et al., 1996. Proc. ODP, Init. Repts., 160: College Station, TX (Ocean Drilling Program).

Hilgen, F.J., 1987. Sedimentary rhythms and high-resolution chronostratigraphic correlations in the Mediterranean Pliocene. Newsl. Stratigr. 17:109-127.

, 1991. Astronomical calibration of Gauss to Matuyama sapropels in the Mediterranean and implication for the geomagnetic polarity time scale. Earth Planet. Sci. Lett., 104:226-244.

Hilgen, F.J., Lourens, L.J., Berger, A., and Loutre, M.F., 1993. Evaluation of the astronomically calibrated time-scale for the late Pliocene and earliest Pleistocene. Paleoceanography, 8:549-565.

Hsü, K.J., Montadert, L., et al., 1978. Init. Repts. DSDP, 42 (Pt. 1): Washington (U.S. Govt. Printing Office).

Jenkins, P., and Williams, D.F., 1984. Nile water as a cause of eastern Mediterranean sapropel formation: evidence for and against. Mar. Micropaleontol, 8:521-534.

Jongsma, D., Fortuin, A.R., Huson, W., Troelstra, S.R., Klaver, G.T., Peters, J.M., van Harten, D., de Lange, G.J., and ten Haven, L., 1983. Discovery of an anoxic basin within the Strabo Trench, eastern Mediterranean. Nature, 305:795-797.

Kidd, R.B., Cita, M.B., and Ryan, W.B.F., 1978. Stratigraphy of eastern Mediterranean sapropel sequences recovered during DSDP Leg 42A and their paleoenvironmental significance. In Hsü, K.J., Montadert, L., et al., Init. Repts. DSDP, 42 (Pt. 1): Washington (U.S. Govt. Printing Office), 421-443.

Kullenberg, B., 1952. On the salinity of the water contained in marine sediments. Goeteborgs K. Vetensk. Vitterhets-Samh. Handl., Ser. B, 6:3-37.

Lourens, L.J., Antonarakou, A., Hilgen, F.J., Van Hoof, A.A.M., VergnaudGrazzini, C., and Zachariasse, W.J., 1996a. Evaluation of the Plio-Pleistocene astronomical timescale. Paleoceanography, 11:391-413.

Lourens, L.J., Hilgen, F.J., Raffi, I., and Vergnaud-Grazzini, C., 1996b. Early Pleistocene chronology of the Vrica section (Calabria, Italy). Paleoceanography, 11:797-812.

McCoy, F.W., Jr., 1974. Late Quaternary sedimentation in the Eastern Mediterranean Sea [Ph.D. thesis]. Harvard Univ., Cambridge, MA.

Mix, A.C., Pisias, N.G., Rugh, W., Wilson, J., Morey, A., and Hagelberg, T.K., 1995. Benthic foraminiferal stable isotope record from Site 849: 05 Ma: Local and global climate changes. In Pisias, N.G., Mayer, L.A., Janecek, T.R., Palmer-Julson, A., and van Andel, T.H. (Eds.), Proc. ODP, Sci. Results, 138: College Station, TX (Ocean Drilling Program), 371412.

Müller, C., 1990. Nannoplankton biostratigraphy and paleoenvironmental interpretations from the Tyrrhenian Sea, ODP Leg 107 (Western Mediterranean). In Kastens, K.A., Mascle, J., et al., Proc. ODP, Sci. Results, 107: College Station, TX (Ocean Drilling Program), 495-511.

Olausson, E., 1961. Studies of deep-sea cores. Rep. Swed. Deep-Sea Exped., 1947-1948, 8:335-391.

Parisi, E., Erba, E., and Cita, M., 1987. Stratigraphy and sedimentation in the anoxic Bannock Basin (Eastern Mediterranean). Mar. Geol., 75:93-117.

Prell, W.L., and Kutzbach, J.E., 1987. Monsoon variability over the past 150,000 years. J. Geophys. Res., 92:8411-8425.

Raymo, M.E., Ruddiman, W.F., Backman, J., Clement, B.M., and Martinson, D.G., 1989. Late Pliocene variation in Northern Hemisphere ice sheets and North Atlantic deep water circulation. Paleoceanography, 4:413446.

Rohling, E.J., and Gieskes, W.W.C., 1989. Late Quaternary changes in Mediterranean intermediate water density and formation rate. Paleoceanography, 4:531-545.

Rohling, E.J., and Hilgen, F.J., 1991. The eastern Mediterranean climate at times of sapropel formation: a review. Geol. Mijnbouw, 70:253-264.

Rossignol-Strick, M., 1983. African monsoons: an immediate climate response to orbital insolation. Nature, 304:46-49.

, 1985. Mediterranean Quaternary sapropels, an immediate response of the African Monsoon to variation of insolation. Palaeogeogr., Palaeoclimatol., Palaeoecol., 49:237-263.

, 1987. Rainy periods and bottom water stagnation initiating brine accumulation and metal concentrations: 1. Late Quaternary. Paleoceanography, 2:333-360.

Ruddiman, W.F., Raymo, M.E., Martinson, D.G., Clement, B.M., and Backman, J., 1989. Pleistocene evolution: Northern Hemisphere ice sheets and North Atlantic Ocean. Paleoceanography, 4:353-412.

Ryan, W.B.F., 1972. Stratigraphy of late Quaternary sediments in the Eastern Mediterranean. In Stanley, D.J. (Ed.), The Mediterranean Sea: Stroudsburg, PA (Dowden, Hutchison and Ross), 149-169.

Ryan, W.B.F., and Cita, M.B., 1977. Ignorance concerning episodes of ocean-wide stagnation. Mar. Geol., 23:197-215.

Ryan, W.B.F., Hsü, K.J., et al., 1973. Init. Repts. DSDP, 13 (Pts. 1 and 2): Washington (U.S. Govt. Printing Office)

Sarmiento, J., Herbert, T., and Toggweiler, J., 1988. Mediterranean nutrient balance and episodes of anoxia. Global Biogeochem. Cycles, 2:427-444.

Shackleton, N.J., Berger, A., and Peltier, W.A., 1990. An alternative astronomical calibration of the lower Pleistocene timescale based on ODP Site 677. Trans. R. Soc. Edinburgh: Earth Sci., 81:251-261.

Shaw, H.F., and Evans, G., 1984. The nature, distribution and origin of a sapropelic layer in sediments of the Cilicia Basin, northeastern Mediterranean. Mar. Geol., 61:1-12.

Smith, D.J., Eglinton, G., and Morris, R.J., 1986. The lipid geochemistry of a recent sapropel and associated sediments from the Hellenic Outer Ridge, eastern Mediterranean Sea. Philos. Trans. R. Soc. London A, 319:375419. 
Sutherland, H.E., Calvert, S.E., and Morris, J.R., 1984. Geochemical studies of the recent sapropel and associated sediment from the Hellenic Outer Ridge, eastern Mediterranean Sea, I. Mineralogy and chemical composition. Mar. Geol., 56:79-92.

ten Haven, H.L., Baas, M., Kroot, M., de Leeuw, J.W., Schenck, P.A., and Ebbing, J., 1987. Late Quaternary Mediterranean sapropels: III. Assessment of source of input and palaeotemperature as derived from biological markers. Geochim. Cosmochim. Acta, 51:803-810.

Thunell, R., Williams, D., Tappa, E., Rio, D., and Raffi, I., 1990. PliocenePleistocene stable isotope record for Ocean Drilling Program Site 653, Tyrrhenian Basin: implications for the paleoenvironmental history of the Mediterranean Sea. In Kastens, K.A., Mascle, J., et al., Proc. ODP, Sci. Results, 107: College Station, TX (Ocean Drilling Program), 387-399.

Tiedemann, R., Sarnthein, M., and Shackleton, N.J., 1994. Astronomic timescale for the Pliocene Atlantic $\delta^{18} \mathrm{O}$ and dust flux records of Ocean Drilling Program Site 659. Paleoceanography, 9:619-638.

Vergnaud-Grazzini, C., Devaux, M., and Znaidi, J., 1986. Stable isotope "anomalies" in Mediterranean Pleistocene records. Mar. Micropaleontol., 10:35-69.

Vergnaud-Grazzini, C., Ryan, W.B.F., and Cita, M.B., 1977. Stable isotope fractionation, climatic change and episodic stagnation in the Eastern
Mediterranean during the Late Quaternary. Mar. Micropaleontol., 2:353370 .

Wijmstra, T.A., Young, R., and Witte, H.J.L., 1990. An evaluation of the climatic conditions during the Late Quaternary in northern Greece by means of multivariate analysis of palynological data and comparison with recent phytosociological and climatic data. Geol. Mijnbouw, 69:243-251.

Williams, D.F., Thunell, R.C., and Kennett, J.P., 1978. Periodic freshwater flooding and stagnation of the eastern Mediterranean Sea during the late Quaternary. Science, 201:252-254.

Zahn, R., Sarnthein, M., and Erlenkeuser, H., 1987. Benthic isotope evidence for changes of the Mediterranean outflow during the late Quaternary. Paleoceanography, 2:543-559.

Date of initial receipt: 28 February 1997

Date of acceptance: 8 September 1997

Ms 160SR-071 